\title{
XLVII. On an unusual affection of the eye, in which three images were produced
}

\section{Griffin Esq.}

To cite this article: D. Griffin Esq. (1835) XLVII. On an unusual affection of the eye, in which three images were produced , Philosophical Magazine Series 3, 6:34, 281-284, DOI: $10.1080 / 14786443508648596$

To link to this article: http://dx.doi.org/10.1080/14786443508648596

册 Published online: 01 Jun 2009.

Submit your article to this journal $\widetilde{ }$

Џ Article views: 2

Q View related articles $₫$ 
Sp. 2. Ozod. gracilis, Westw. Fusco-ochracea ; rostro subfulvo; antennis fuscis, basi ochraceis ; thorace subvittato; alis subfimosis, nervis stigmateque ochraceis.-Long, corp. lin. 10. $\delta$.

Habitat in Brasiliâ.-In mus. nostr.

Cerozodia, Westw. (Ozocera, IVestw, Zool. Journ. No. 20. ined.-nec Ozodicera, Macq.)

Limnobice affinis. Antennæ thorace paulò longiores, articulis 32; 3-31, ramulum longum emittenti. Palpi perbreves. Alarum nervi ut in Gynoplistiá vili dispositi.

Sp. 1. Cer. interrupta, Westw. Ochracea; ramulis antennarum subfuscis; alis maculis 4 parvis discoidalibus longitudinaliter collocatis, cinereis.Long. corp. lin. 10. In mus. D. Hope.

Habitat in Australiâ apud "Swan River."

\section{Bitracomorina, Westw.}

Genus anomalum Tipulariis terricolis, Latr., evidenter pertinens. Caput et thorax parva. Abdomen valdè elongatum et depressum. Pedes longitudine mediocres; femoribus tibiisque gracilibus; tarsis basi dilatatis densè ciliatis. Alæe nervis perpaucis, ferè ut in genere Sciophilâ dispositis. Antennæ graciles, filiformes. Palpi capitis longitudine, articulis 4 æqualibus. Lobi labiales magni. Ocelli 0 ?

Sp. 1. Tipula clavipes, Fab. Sp. Ins. 2. 404. Ptychoptera clavipes, Fab. Syst. Rhyng. Wied. Auss, Zweifl. Ins. 1. 59.-Long. corp. liv. 8. Exp. alar. lin. 8.

Haibitat in Americâ Boreali. In Insulâ Newfoundland.-In mus. nostr. -Commun. Dom. Churton.

Midas maculiventris, Westw. Obscurè niger; abdomine testaceo-fuscanti, segmentis apice pallidis et (nisi segmentis duobus basalibus) maculâ triangulari obscurầ in medio notatis; hæ maculæ versus apicem abdominis magnitudine crescunt : segmento anali fusco; abdomine toto subtùs concolori; alis flavido-fuscantibus, regione nervorum internorum colore obscuriori tinctâ.-Long. corp. lin. 11. Exp. alar. lin. 19.

Hab. ?-In mus. nostr.

Mivas auripennis, Westw. Niger; capite cum antennis, pedibus (nisi basi femorum) abdonine (nisi segmento basali marginibusque terminalibus segmentorum $\mathscr{2}$ et 3 ,) latè luteis; alis auricoloribus, maculâ versus apicem costa nigrâ, margineque interno pallido, mesosterni lateribus unispinosis. Alarum nervorum directio Midasibus veris paulò discrepat.-Long. corp. lin. 11. Exp. alar. lin. 19.

Habitat in Novâ Hollandiâ. In mus. Hope et nostr.

Midas viduatus, Westw. Niger; faciei thoracisque lateribus, et maculầ triangulari utrinque ad basin segmentorum 3 et 4 abdominalium, sericie argenteâ obtectis; alis pallidis in medio fuscantibus, nervis fuscis.-Long. corp. lin. 10. Exp. alar. lin. 16.

Habitat in Novâ Hollandiâ.-. In mus. nostr.

XLVII. On an unusual Affection of the Eye, in which three Images were produced. By D. Griffin, Esq.*

THE following affection of the eye is, I believe, a very unusual one. I have seen no account of such a phæriomenou in any of the writings on the physiology of vision, and

* Communicated by the Author.

Third Serics. Vol. 6. No. 34. April 1835. 


\section{Mr. D. Griffin on an unusual Affection of the Eye.}

shall feel gratified if I can learn whether it has ever been observed by others.

One day in the early part of last Julv, after having spent a considerable time in looking at various land objects through a telescope, 1 perceived a very great indistinctness of vision after I had left off; which I soon found existed entirely in the left eye. I had kept this eye closed while I was at the telescope; and having often observed before that some indistinctness of vision occurred in the same circumstances, I attributed it to the weakness of sight that would naturally follow from having kept that eye unemployed while using the other, and did not mind it much at first. It seemed now, however, so great that I covered the right eye to examine the state of the other more particularly.

I then found, with some surprise, that it gave more than one image, and on directing it towards a box on the chimneypiece, about eight or nine feet from me, on the front of which were some large and extremely well printed letters, I perceived that there were three distinct images of those letters placed vertically one above the other. The lowest, which I shall call the true image, was undisturbed from its proper place. The dislocation of the second image was just so great as to make it overlap more than the upper half of the lastmentioned, and its light was scarcely, if at all, inferior to that of the true one. The light of the third was much more faint than that of either of the others, and its displacement was such as to allow it still slightly to overlap the true image at its upper edge, where the combination of the three images produced a dark line along the letters exactly similar in appearance to overlying shadows. There was not the least displacement towards either side, unless I changed my head from an erect position; and I could not find any trace of a fourth image by the closest examination. This affection lessened gradually in the course of the evening, the false images slowly descending to their true place, and next day that eye was as perfect as the other.

I was for some time puzzled to account for this strange appearance. It seemed difficult to suppose that any functional derangement of the retina conld give origin to three images so distinct and separate; and though a double image is sometimes an attendant upon amaurotic affections of the eye, yet this, so temporary in its nature, could hardly be classed with such complaints. The cleanness and good definition of the images seemed to indicate some optical change; and besides this, the distortion occurring all in one plane evidently pointed to some single cause, and that probabiy a mechanical one, as the origin of the whole phanomenon. 
The effect, however, produced was such as would result from a distortion or bending back of the upper part of the crystalline lens, producing an effect not exactly like spherical aberration, but like what would arise from the axis of that part of the lens losing its parallelism to the axis of the centre and other parts, which would tend to throw the image produced by that part in the direction in which the distortion of the axis lay.

In order that a correct idea may be formed of the degree of the displacement, it is necessary to mention that the letters which I looked at, at the distance of three yards, and of which the different images were separated to the degree mentioned above, were about $\frac{3}{4}$ ths of an inch in height and about the same in breadth.

'The only thing that occurred to me that could produce such a distortion was the pressure of the upper eyelid on the eyeball, which was very considerable and long continued. That the distortion was in the lens alone seems probable, because, from its half-solid state, it is almost the only part of the eye that would retain the effect of pressure for any time; but if the altered shape of the lens was the cause, the alteration must have been an exceedingly peculiar one. To produce the three images above mentioned it must have had two sudden bendings backwards; one somewhere near the middle, and the other near the upper edge. The lower half, which I suppose to have been undisturbed, would in that case have given the true image; the part immediately above, which was bent backwards in some degree, would have formed an image lower on the retina, and therefore higher to the perception than the true one; and the highest part, or upper edge, of the lens, which was most distorted, would have given the lowest image on the retina, and therefore the highest to the perception. But here came the difficulty: on considering the structure of the lens as far as that is at present known, and how its density lessens gradually from the centre to the circumference, it seemed extremely hard to suppose that any bending could take place in it otherwise than very gradually, and in a regular curve. This gradual bending, it is evident, would not be indicated by the perception of multiplied images, but by great indistinctness and haziness in the upper part of the object; yet of either haziness or deficiency of outline in the images there was not the least appearance.

I have tried repeatedly since to produce the same appearance by simply covering the left eye while using the right, and otherwise observing the same circumstances, but I found that $20 \%$ 
284. Prof. Forbes on the Refraction and Polarization of Heat.

the pressure of the eyelid was always essential to the success of the experiment.

I have only further to add, that I should be glad to have the opinions of those who are interested in the physiology of vision on this curious fact, as I find it exceedingly hard to conceive how such a change in the lens as I have supposed, could be produced by any pressure, however exercised, of the eyelid.

Pallas Kenry, Feb. I, 1835.

D. Griffin.

XLVIII. On the Refraction and Polarization of Heat. By JAMes D. Forbes, Esq., F.R.SS. L. \& E., Professor of Natural Philosophy in the University of Edinburgh.

[Continued from p. 214.]

\$. 4. On the Depolarization and Double Refraction of Heat by Crystals.

46. THE analogies which have hitherto guided us from the laws of light to those of heat, suggest that it is far from improbable that the influence of crystallized bodies upon polarized light, which produces the most splendid and most varied, but, at thesame time, amongst the most determinate phænomena of optics, may have a counterpart in the science of heat. The simpler of these, of course, it is our object first to verify: and, to a certain extent, this is all that is necessary, in order to complete the analogy of heat and light in this particular case; for the conditions essential to their production in the case of light, are on all hands admitted to depend on the susceptibility of the principle of light to undergo certain modifications in certain circumstances, extremely limited in number, and which then produce, as necessary consequences, all the subsequent effects. If we find that heat undergoes the same changes under the same circumstances, so far as we can detect them, there is the highest probability in favour of the extended analogy; for if there be a necessary sequence in the one case, it must be inferred also in the other.

47. When polarized light is caused to pass through a crystallized body possessing the power of double refraction, it happens, in a great majority of the conditions under which the experiment may be made, that the light, on emerging from the crystal, has undergone some change. This change may, for instance, render it capable of reflection at a surface inclined to the rays of light at the polarizing angle, which they were incapable of doing before the crystal was interposed, or if be- 